\title{
Community Service Of Agro Tourism In Sibetan Village
}

\author{
P.A.K Juniarta* \\ English Language Education, Faculty of Language and Art, Undiksha
}

\section{A R T I C L E I N F O}

Article history:

Received 20 December 2018

Received in revised form

1 January 2019

Accepted 30 January 2019

Available online 27

February 2019

Keywords:

agro tourism facilities,

management of agro

tourism, promotion and

marketing,

\section{A B S T R A C T}

The development of tourism in Indonesia in line with the government's program to promote tourism as an effort to increase foreign exchange outside the oil and fuel sector. One potential alternative which could be developed in the village was agro tourism, which has been started to be developed and many of them were already successfully managed. Rilla, et al (1999) stated that the agro-tourism development should be an opportunity for local farmers to increase their income for their family. Two groups that became the partners in this community service were Abian Salak agro tourism farmer group and Kebun Salak agro tourism farmer group in Sibetan village. They were selected as the partner in the activities of this program because they had same problems, namely they had low knowledge in managing their agro tourism and low knowledge in promoting their agro-tourism to the public especially for domestic or international travelers who have interest in agro-tourism. The solutions that were done by the team to overcome these problems were providing the training of agro tourism management that was attractive and sustainable, assisting the farmer in providing essential facilities to support activities that was offered by agro-tourism as well as their knowledge to take care those facilities, and training the farmer in promoting their agro-tourism by using offline media (brochures and joining some activities of tourism festival) and online media (agro-tourism website and the use of social media). The methods that were used in these activities were assisting and training the farmer in managing their agro tourisms and promoting them to the costumers. Those problems could be solved and could give a positive impact to the agro tourism management that was attractive and sustainable.

\footnotetext{
* Corresponding author.

E-mail addresses: adiputu108@gmail.com (P.A.K Juniarta)
} 


\section{Introduction}

Tourism is one of the growth industries in the world. This is because most of the countries in the world get their foreign exchange from tourism sector. In addition, tourism is also a strategic activity if it is viewed from economic and social culture because it encourages some jobs vacancy, improves a development of investment, increases people's income, improves the quality of society, and can increase patriotism of our nation (Downing, 2011).

One potential alternative to be developed in the village is ecotourism/agro-tourism, which was recently begun and many of them were already successfully managed. This agro-tourism is a special kind of tourism which makes agricultural, livestock, and farm as an attraction to attract tourist. Rilla, et al (1999) stated a similar opinion about it, the tourism development should be an opportunity for local farmers to increase their income. It educates people to learn about agriculture in order to increase their income, it can reduce urbanization, the youth who are still in productive age do not need to go to the city for working because they can get job by joining the agro tourism management, and agro-tourism can be as a media that is used to promote the local product to the international market. This statement in line with Sutjipta (2001) that defines, agro-tourism is a system of integrated activities for the development of tourism which has relationship to environment conservation and the prosperous enhancement of the farmer communities.

Agro tourism salak in Sibetan village is one of the attractions which was owned by Karangasem Regency, Bali. This attraction is precisely located in the Bebandem district, Sibetan village, Karangasem Regency, Bali. Sibetan village is famous known because of agricultural product such as snake-fruits (salak) that becomes a mainstay of farmers. This village has mountainous geographical conditions with wet till dry climatic conditions. This situation was perfect for snake-fruit plants grow and produce the fruits. Snake-fruit agricultural land in this village is vast which own privately by the farmer and managed by farmer groups. The fruits are very sweet, soft and larger than the fruits which produced by other regions. But it is not a good farmer source because it cannot make the stability of the farmers' economy. A lot of problems encounter by farmers in producing and marketing the snake-fruits. Its price has fluctuated extremely, particularly vulnerable plummeted during the harvest time. Those problems become the factor which made a number of farmers in Sibetan back to plant rice because the rice's price higher than the price of the snake-fruit.

In every year, the farmers harvest the snake-fruit in Sibetan twice, the peak period from January to March and the second period which has smaller amounts in August and September. According to Sepel, one of the farmer, every year farmers can harvest about $3 \mathrm{~kg}$ per tree. With a total planting area of $5000 \mathrm{~m} 2$ on average contains 1,200 trees, each farmer can harvest approximately 1.8 tons per harvest, or about 3.6 tons per year. The amount is so large. When the snake-fruits are abundant supply at harvest time, prices fell uncontrollably. Bali snake-fruit which normally have price from Rp 5,000 / Kg turned into $\mathrm{Rp} \mathrm{1,000} \mathrm{/} \mathrm{kg} \mathrm{at} \mathrm{harvest} \mathrm{time.} \mathrm{This} \mathrm{makes} \mathrm{the} \mathrm{farmer} \mathrm{become} \mathrm{frustrated} \mathrm{and} \mathrm{let} \mathrm{it} \mathrm{to} \mathrm{be} \mathrm{purchased} \mathrm{rather}$ than it left to rot in the garden.

Based on the phenomenon which explained above, the agro tourism was developed by several groups of farmers in this village as an effort to solve that issue. But only a little amount of agro-tourism developed by farmer groups in this village due to lack of knowledge in developing agro-tourism and in doing promotion to attract the attention of tourists or visitors who are interest to visit agro tourism. Two groups that play an active role of the development of agro tourism itself are Abian Salak Agro Tourism and Kebun Salak Agro Tourism in Sibetan village.

Both of the two farmer groups had the problem when managing their agro tourism. They needed to be educated about the way how to manage agro tourism in a good management and attractive, and the use of science and technology in promoting the agro tourism in order to increase the number of visitors and be able to compete with the other tourism spots. It will give some impact in improving the economy of farmer groups and local communities through increased tourist visit, both domestic and international. Therefore, the team proposed some solutions based on the application of science and technology which related to the problems faced by the partners so that agro tourism can run well and have competitiveness.

\section{Method}

The method used by the team in this community service was assisting and training the farmer about agro tourism management, providing the tools and facilities that supported the agro-tourism attractions or activities, giving information about the facilities and equipment maintenance, mentoring and training about promotion that used online and offline media. 
The stages of the implementation of agro tourism community service in Sibetan farmers group were as follows: (1) the stage of assisting and providing information about good, attractive and sustainable agro tourism management. It was done in order to improve the knowledge of partners in managing their agro tourism, (2) the stage of analyzing facilities that should be equipped to support attractions or activities in agro tourism, (3) the stage of providing the facilities that supported the attractions and activities in the agro-tourism, (4) the stage of sharing knowledge about the facilities maintenance which should be routinely implemented, (5) the stage of assisting and training about the use marketing media both offline and online, and (6) the stage of assisting and training the farmer about the way how to manage media content in the promotion media.

Every activity carried out by both parties were monitored and evaluated by the team with the aim of achieving the objectives of the activity on time. So at the end of this activity, positive changes could be seen such as increasing partners' abilities and knowledge in managing agro-tourism, increasing partner awareness of the importance of supporting facilities and attractions in agro-tourism, increasing the ability of partners to do marketing and promotion online and offline which impacts on tourists and visitors visits to agro-tourism. Through this PKM activity, it was expected that tourist visits, both domestic and international, could increase so that it had an impact on the income of partners and the surrounding community.

Both the team and partners continued to maintain communication intensively after this activity had been conducted. The team monitored whether there were obstacles in agro-tourism management after the activities were completed. If there are obstacles or problems occurred, the team will provide assistance in overcoming these obstacles in accordance with the context of the activities that has been done before. Partners also will provide reports on agro-tourism activities that they manage to the team and consult when there are obstacles or innovations that must be carried out in accordance with this activity.

\section{Finding And Discussion}

The implementation of this community service activity was initiated from a discussion which was held by the partners (farmers) and teams. In the discussion, the team described the stages carried out during the implementation that involved the partner themselves. Partners could understand and followed the instructions that explained by the team. The activities that had been done by the team and partners in implementing agro tourism community service were assisting and providing information about good, attractive and sustainable agro tourism management, analyzing facilities that should be equipped to support attractions or activities in agro tourism, providing the facilities that supported the attractions and activities in the agro-tourism, sharing knowledge about the facilities maintenance which should be routinely implemented, assisting and training about the use marketing media both offline and online, and assisting and training the farmer about the way how to manage media content in the promotion media. Those activities can be seen as follows:
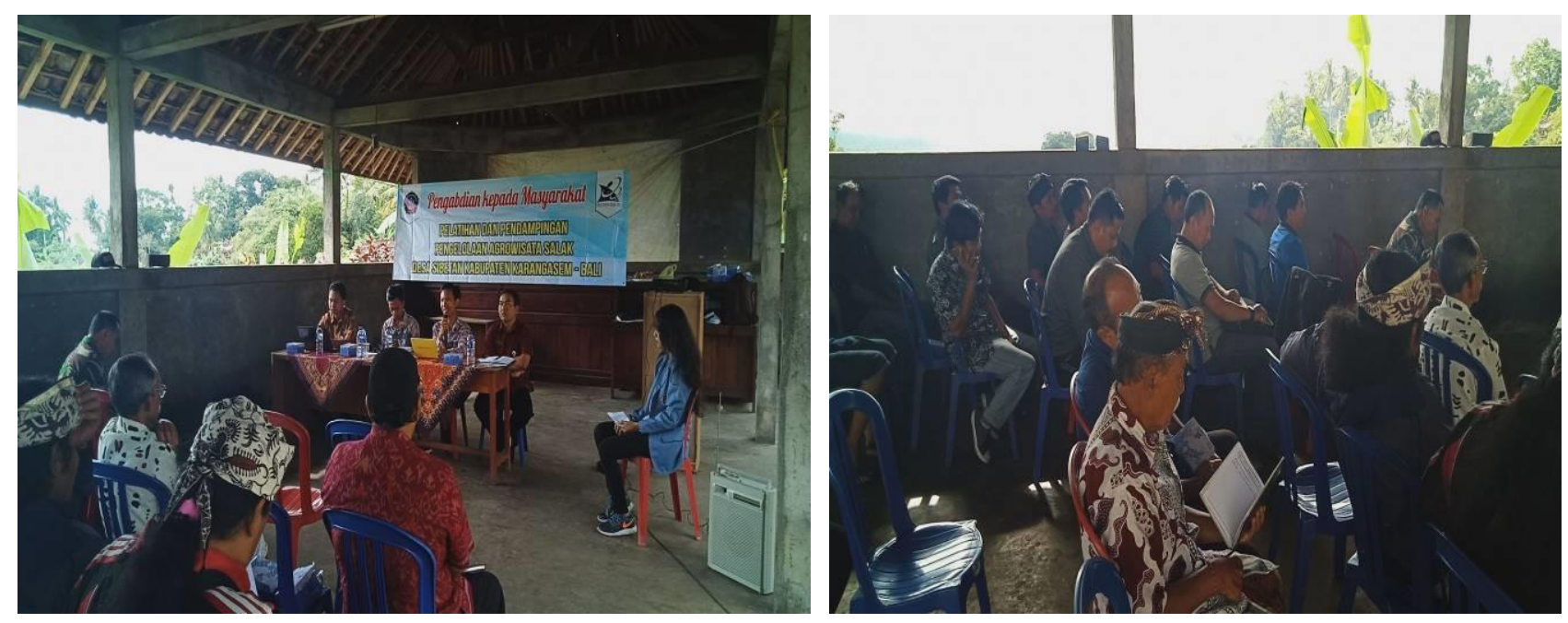

Figure 1. Training and counseling activities about agro tourism management 
After the implementation of those activities, the positive impact can be seen. They were the development of the partner's competency in managing the agro tourism and the increase amount of tourist visit in the partner's agro tourism. The improvement of partners' competency in managing agro tourism could be known by interviewing the partners directly. Partners could answer all the questions that were asked by the team about how to manage good agro tourism. In addition, tourist visit increased could be seen by comparing the number of tourist visit before this community service activity conducted (10-15 visitors every month) with the number of tourist visit after this community service activity conducted (25-35 visitors every month). There was an improvement of tourist visit in agro tourism. It showed that the implementation of these activities gave a good impact to the partner

\section{Conclusion}

This community service activity gave positive impact to partners such as: 1 . Improving the partner's competency in managing agro tourism that gave an impact to the agro tourism could be known in the tourism field. 2. The fulfillment of facilities and equipment could support tourist activities in the agro tourism itself. 3. The improvement of the farmer's knowledge in using science and technology in promotion and marketing media both offline and online. It made agro tourism could be known by the public especially domestic or international travelers who had interest in agro tourism.

\section{Reference}

Downing, A.J. 2011. The Architecture of Country House. FG Press: California

Mayantari, Ni Wayan. 2016. Penerapan Strategi Pemasaran dalam Meningkatkan Tingkat Hunian Wisata. Jurnal Bisnis dan Kewirausahaan. 12(2). 146-156

Rilla, E. (1999). Bring the City \& County Together. California Coast and Ocean journal. 15(2). 1-10.

Sutjipta, I Nyoman. (2001). Agrowisata. Magister Manajemen Agribisnis: Universitas Udayana.

Syamsu, dkk. 2001. Penerapan Etika Perencanaan pada kawasan wisata, studi kasus di kawasan Agrowisata Salak Pondoh, Kabupaten Sleman, Daerah Istimewa Yogyakarta. Jakarta: LP3M STP Tri Sakti. Jurnal Ilmiah. 5(3). 21-32

Utama, I Gst Bagus Rai. 2012. Agrotourism as an alternative form tourism in Bali. CHN Dissertation: Netherlands.

Umami, Z. 2015. Social Strategi pada Media Sosial untuk Promosi Pariwisata Daerah Istimewa Yogyakarta. Jurnal Interaksi. 4(2). 195-201 